\title{
CORRECTING MISCONCEPTIONS ABOUT THE NAMES APPLIED TO TASMANIA'S GIANT FRESHWATER CRAYFISH ASTACOPSIS GOULDI (DECAPODA: PARASTACIDAE)
}

\author{
by Terrence D. Mulhern \\ (with three plates)
}

\begin{abstract}
Mulhern, T.D. 2018 (14:xii) Correcting misconceptions about the names applied to Tasmania's Giant Freshwater Crayfish Astacopsis gouldi (Decapoda:Parastacidae). Papers and Proceedings of the Royal Society of Tasmania 152: 21-26.

https://doi.org/10.26749/rstpp.152.21 ISSN 0080-4703. Department of Biochemistry and Molecular Biology, School of Biomedical Sciences, The University of Melbourne, Vic 3010, Australia. Email: tmulhern@unimelb.edu.au
\end{abstract}

\begin{abstract}
Tasmania is home to around 35 species of freshwater crayfish, all but three of which are endemic. Among the endemic freshwater crayfish, there are three large stream-dwelling species: the Giant Freshwater Crayfish, Astacopsis gouldi - the world's largest freshwater invertebrate, the medium-sized A. tricornis and smaller $A$. franklinii. Errors and confusion surrounding the appropriate Aboriginal names for these species, and the origin and history of the scientific name of Astacopsis gouldi are outlined.
\end{abstract}

Key Words: Tasmanian freshwater crayfish, giant freshwater lobster, Giant Freshwater Crayfish, Astacopsis gouldi Aboriginal words, lutaralipina, tayatitja, scientific names, William Buelow Gould, Charles Gould.

\section{INTRODUCTION}

Tasmania is home to three species of large stream-dwelling freshwater crayfish assigned to the endemic genus Astacopsis. Of these three species, Astacopsis gouldi Clark, 1936, known commonly as the Giant Freshwater Crayfish, or 'lobster', is the world's largest freshwater invertebrate. A. gouldi is found in northern Tasmania and the medium-sized $A$. tricornis Clark, 1936 and smaller $A$. franklinii (Gray, 1845) are found in southern Tasmania, in the west and east, respectively (Richardson et al. 2006). In the period since they were first described by European naturalists, there have been several revisions of the nomenclature for these animals. Here, the history of the naming and classification of these species is outlined, from the pre-colonial period, through to the current era of molecular genetics. The appropriate assignment of Aboriginal names is discussed to address past and ongoing misattribution. This is followed by a résumé of the confusion surrounding the etymology of the specific name given to the Giant Freshwater Crayfish, in the context of the history of the nomenclature and classification of the three species. Finally, the misconceptions surrounding the origin of the epithet gouldi are addressed.

\section{TASMANIAN ABORIGINAL NAMES FOR FRESHWATER CRAYFISH}

Freshwater crayfish were eaten by Tasmanian Aborigines (Roth 1899, Noetling 1910, Hiatt 1967, Plomley 2008). The word list of Tasmanian Aboriginal languages compiled by Brian Plomley contains two different words for these animals (Plomley 1976, p. 262). The first is 'tate.yer' for which Plomley lists two variant transliterations taken from G.A. Robinson's notes from the 1830s: 'tate.yer' from the eastern Oyster Bay tribe; and 'tate.te' from the Bruny Island tribe in the far south. Plomley also lists a further two variants from Joseph Milligan's later vocabulary: 'tayatea' (Oyster Bay) and 'tay-a-teh' (Bruny Island/South) (Milligan 1859). It is important to note that these were English transliterations of Aboriginal words, as heard by the recorders, none of whom were trained linguists, and interpretation of the significance of differences requires linguistic analysis. Plomley also listed another, quite different, word describing freshwater crayfish: 'loe.ter.er.le.pe.en.ne' (Plomley 1976, p. 262). This word was recorded by G. A. Robinson in the 1830s from the Cape Portland tribe of the northeast. Plomley suggested that this word refers to:

"... a northern one which grows to a large size, some-

times as long as sixty centimetres, and is known as

the Freshwater Lobster..." (Plomley 1976, p. 262),

by which he means what is now known as $A$. gouldi. Considering the geographic distributions of these animals (Richardson et al. 2006), we can be almost certain that 'tate. yer' and its variants refer to the smallest of the three species, A. franklinii, as this is the only member of the genus found in southeastern Tasmania. Whether 'loe.ter.er.le.pe.en.ne' refers exclusively to the Giant Freshwater Crayfish $A$. gouldi is less certain, as the Cape Portland tribal region includes areas where $A$. gouldi and $A$. franklinii are found separately, as well as the narrow strip where their distributions overlap. Sadly, no western language group words were recorded for freshwater crayfish, so no Aboriginal name is available for A. tricornis.

In recent times it has been common to use 'tayatea' as the Aboriginal name for $A$. gouldi (Threatened Species Section 2006, Richardson 2008, Shepherd et al. 2011, Reynolds et al. 2013, Anon 2017). While recognition of Aboriginal natural history knowledge is appropriate and to be encouraged, the historical record does not support the use of this word for this species. Furthermore, the misattribution of 'tayatea' extends beyond the genus 
Astacopsis. Engaeus tayatea Horwitz, 1990, a burrowing crayfish found in the northeast of Tasmania, was named with the following explanation: "The specific epithet was taken from the aboriginal word for 'freshwater lobster' (Plomley 1976)" (Horwitz 1990 p. 605).

The palawa kani Language Program of the Tasmanian Aboriginal Centre has revived 'lutaralipina' (pronounced: lu-tar-rah-lee-pee-nah) as the appropriate Tasmanian Aboriginal term for the Giant Freshwater Crayfish ( $A$. gouldi); and 'tayatitja' (pronounced: tie-yah-tee-tchah) for the small Southern Freshwater Crayfish (A. franklinii). Palawa kani is the only Aboriginal language now spoken in lutruwita (Tasmania) and its alphabet is linguistically designed to represent the original sounds of Aboriginal words that were recorded by Europeans (Tasmanian Aboriginal Centre 2018).

\section{HISTORICAL OVERVIEW OF ASTACOPSIS NOMENCLATURE}

The early European explorers and settlers ate freshwater crayfish (Gould 1870, Crawford et al. 1962, Plomley 2008), but it was not until the middle of the nineteenth century that the first scientific study of Tasmanian freshwater crayfish was published (Gray 1845). John Edward Gray in his 'Descriptions of some new Australian animals' included "The Van Diemen's Land Cray-fish. Astacus Franklinii” (Gray 1845 , p. 409). He named the animal after Sir John Franklin, the famed Arctic explorer and lieutenant-governor of Van Diemen's Land from 1837-1843, who, together with his wife Lady Jane Franklin (née Guillemard), were great patrons of science and the arts in the new colony. Surprisingly, despite the striking difference in adult size between the giant freshwater 'lobster' and the smaller southern crayfish, all Tasmanian stream-dwelling freshwater crayfish were still classified as a single species under the name Astacus/Astacopsis franklinii until the turn of the twentieth century.

A first attempt to differentiate between the northern and southern stream-dwelling freshwater crayfish was made in 1908-09. The English naturalist Geoffrey Smith, Fellow of New College Oxford, spent six months in the austral spring and summer of 1907-08 travelling around Tasmania and making observations of the flora and fauna. He described these observations in his book $A$ Naturalist in Tasmania (Smith 1909) and in a contemporaneous paper, specifically on freshwater crustaceans, in the Transactions of the Linnean Society of London (Smith 1908). In $A$ Naturalist in Tasmania, Smith describes being taken fishing near Bridport in northeastern Tasmania and catching and eating a large freshwater crayfish:

"This Crayfish is the largest in the world, and is quite a distinct species from the small Crayfish which is found in the creeks of the southern part of the island, and which never grows to more than five or six inches."

(Smith 1909, p. 110)

In both publications he referred to the large northern crayfish as $A$. franklinii. In the Transactions paper he described the smaller southern crayfish as $A$. tasmanicus
(Smith 1908, p. 70) following the work of the German naturalist Wilhelm Ferdinand Erichson (1846). Perhaps Smith could not read German, because it is quite clear from the details of its habits as described by Erichson, and related to him by his local collector Adolphus Schayer, an employee of the Van Diemen's Land Company, that Erichson's A. tasmanicus was a burrowing crayfish, rather than a stream-dwelling species. Smith published again a few years later, seeming to wrestle with whether or not his misnamed $A$. tasmanicus was indeed a separate species, or simply a smaller variant of $A$. franklinii:

"In the highland streams of the south and centre a small form occurs (var. tasmanicus) which may or may not be reckoned as a separate species". (Smith 1912, p. 149)

In 1936 Ellen Clark published a comprehensive revision of stream-dwelling and land crayfish of Australia (Clark 1936). Clark reclassified the burrowing crayfish Astacus tasmanicus Erichson, 1846 as Parastacoides tasmanicus Clark, 1936 when she erected that genus. Clark, an otherwise excellent taxonomist, unfortunately never saw the type species that Schayer collected and passed on to Erichson. If she had, she would not have used "tasmanicus" as one of her species names in Parastacoides, because the specimen is actually a species of Geocharax, no doubt collected from northwest Tasmania, where Schayer was active (Richardson 2017). Clark also split Astacopsis franklinii, erecting Astacopsis gouldi and Astacopsis tricornis, for the northern and western forms, respectively and restricting the name $A$. franklinii to the southern forms (Clark 1936). However, further changes followed. In midtwentieth century Riek (1969) published another Tasmanian species, Astacopsis fluviatilis. Subsequently, A. fluviatilis and A. tricornis were synonymised with $A$. franklinii (Swain $e t$ al. 1982). A decade later, Premek Hamr's (1992) revision reinstated $A$. tricornis as a valid species - thus restoring the situation defined by Clark more than half a century earlier. Hamr sampled very widely across Tasmania and was able to make a detailed assessment of certain key morphological features (e.g., width of and number of ridges on the rostrum at the front of the head) and the significant differences in the average size of adults. Subsequently, the genetic distinctiveness of these three species was confirmed by biochemical analysis at the close of the twentieth century (Avery \& Austin 1997). In recent years, direct analysis of genetic differences by mitochondrial genome sequencing has supported these earlier morphological and biochemical studies (Sinclair et al. 2011, Gan et al. 2017).

\section{ONGOING NAMING CONFUSION}

Gray's 1845 sketch of the giant crayfish (pl. 1) was always somewhat hidden from the public eye, due to it being published in an Appendix to the journals describing Edward John Eyre's exploration of central mainland Australia (Eyre 1845). However, in recent time it is an earlier artistic rendering of one of these animals that has captured the public imagination. This image is an exquisite watercolour called the 'Freshwater Crayfish' (pl. 2) by the celebrated 
PLATE 1 - Sketches of Australian freshwater crayfish. From John Edward Gray's Description of Some New Australian Animals (Gray 1845), which appeared as an appendix to Edward John Eyre's Journals of Expeditions of Discovery into Central Australia and Overland from Adelaide to King George's Sound (Eyre 1845). The main image is described as The Van Diemen's Land Cray-fish. Astacus Franklinii [possibly Astacopsis gouldi]. The lower right partial image is: The Western Australia Cray-fish. Astacus quiquecarinatus [now known as Cherax quinquecarinatus]; and lower left partial image is: The Port Essington Cray-fish. Astacus bicarinatus [now known as Cherax bicarinatus].
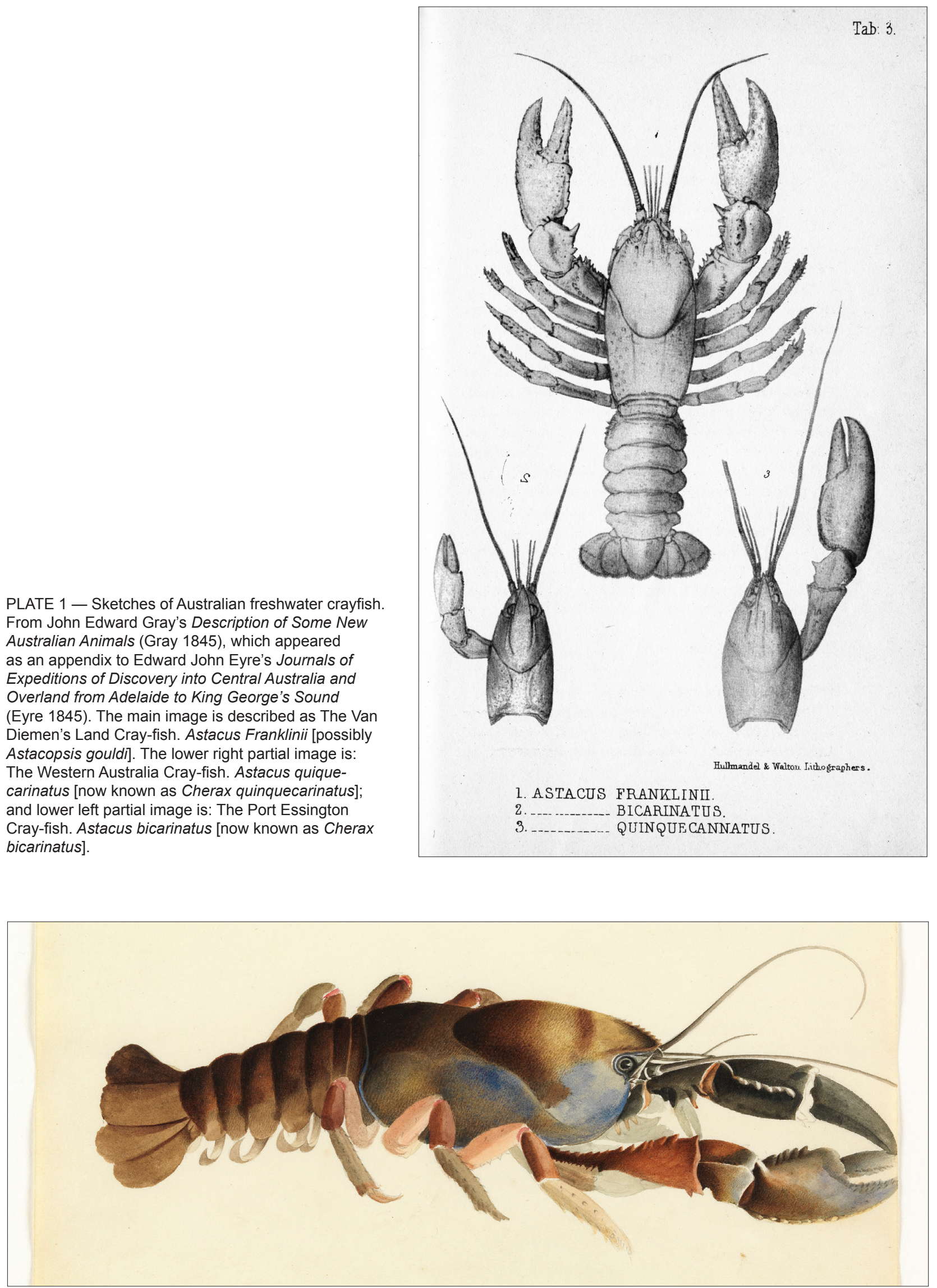

PLATE 2 - The 'Freshwater Crayfish' (most likely Astacopsis tricornis) in Gould's Sketchbook of Fishes (Gould c. 1832). Watercolour on paper by Willian Buelow Gould, painted at Macquarie Harbour. [Reproduced with the permission of the Allport Library and Museum of Fine Arts, Tasmanian Archive and Heritage Office.] 
convict artist William Buelow Gould (c.1832). However, two tenacious misconceptions have developed around this painting. Firstly, it is widely believed that the painting is of the Giant Freshwater Crayfish $A$. gouldi - it is not. The painting is almost certainly the western species, $A$. tricornis. Secondly, because of the first misconception, it is common to believe that $A$. gouldi was named after the artist Gould - it was not. The scientific name of the Giant Freshwater Crayfish was chosen by Clark (1936) to honour the geological surveyor Charles Gould (1834-1893).

William Buelow Gould (c. 1832) (pl. 3) painted the 'Freshwater Crayfish' at Macquarie Harbour. Gould, whose real name was Holland, was a painter of ceramics who was transported in 1827 for theft. He was an alcoholic and this led to further offences in Van Diemen's Land: he was sentenced to secondary punishment, twice at Macquarie Harbor, and later at Port Arthur. On Sarah Island in Macquarie Harbour his artistic talents ameliorated the conditions of his imprisonment, as he was assigned as house servant to the settlement's medical officer, Dr William de Little, and painted natural history specimens for the doctor (Meade 1959, Allport 1966). W.B. Gould's (c. 1832) Sketchbook of Fishes comprises 36 images of aquatic fauna from around Macquarie Harbour. It is held in The Allport Library and Museum of Fine Arts in Hobart. It is considered Gould's finest work and has been recognised as a national treasure (National Library of Australia 2007). Gould's sketchbook inspired Richard Flanagan's (2001) humorous and fantastical novel Gould's Book of Fish: A Novel in Twelve Fish. The freshwater crayfish features in chapter 10, where Flanagan's protagonist, the escaped convict Billy Gould, encounters a newly moulted freshwater crayfish on a rock by an alpine tarn.

The misconception, that Gould's painting depicts A. gouldi, was popularised in Robert Hughes' book on Australia's convict period The Fatal Shore (Hughes 1987) and has since been perpetuated widely (Richardson 2008, Tasmanian Museum and Art Gallery 2013, Anon. 2017). The second misconception, that $A$. gouldi must have been named after William Buelow Gould has also become prominent (Hughes 1987, Tasmanian Museum and Art Gallery 2013, Anon. 2017). Although any documentation associated with de Little's collection has not survived, based on morphological detail evident in the painting and the most likely geographical location of its collection (the lower reaches of the Gordon River), it was noted by Hamr (1992) that the painting is most probably of $A$. tricornis. Whether by accident or design, Flanagan's fictional encounter between Billy Gould and the freshwater crayfish also supports the correct identification. By placing it in an alpine environment, Flanagan immediately marks it as $A$. tricornis, as $A$. gouldi is found only at low altitudes.

In terms of the basis of the naming of $A$. gouldi by Ellen Clark (1936), she neither mentioned the artist W.B. Gould nor the painting 'Freshwater Crayfish', but rather highlighted the many pertinent observations on the giant freshwater 'lobster's' distribution, diet and habits made by the government geologist, Charles Gould. Like many scientists of his day, Charles Gould ventured beyond his specialisation, and he published 'On the Distribution and Habits of the Large Fresh-Water Crayfish (Astacus Sp) of the Northern Rivers of Tasmania' in the Monthly Notices of Papers and Proceedings of the Royal Society of Tasmania (Gould 1870). In his paper, Gould noted that:

"I am not aware that this has been specifically described by naturalists, although its unusually large size, abundance in certain localities, estimation as a delicacy for the table, added to its facility of capture and observation should long since have acquired for it that attention at their hands." (Gould 1870, p. 42)

\section{CONCLUSIONS}

Linguistic research and the revival of Tasmanian Aboriginal language have provided clarity on the appropriate Aboriginal terms ascribed to Astacopsis gouldi and Astacopsis franklinii. Hopefully, future interrogation of historical sources will reveal an Aboriginal name for Astacopsis tricornis. Unsurprisingly, the romantic notion of a giant freshwater 'lobster' being named after a convict artist, who painted a delicate and nuanced watercolour of it while incarcerated in a convict hellhole is common. Sadly, these are both misconceptions - the painting was almost certainly a different species and the 'lobster' Astacopsis gouldi was not named for the artist William Buelow Gould; it was named in honour of the government geological surveyor and field naturalist, Charles Gould.

\section{ACKNOWLEDGEMENTS}

I acknowledge Tasmanian Aborigines as the traditional owners of lutruwita, the land that is the focus of this research. I also acknowledge the traditional owners of the land on which I live and work, the Wurundjeri people of the Kulin Nations. I pay my respects to both sets of Elders, past, present and future. I am grateful to Annie Reynolds and Theresa Sainty from the palawa kani Language Program at the Tasmanian Aboriginal Centre for helpful discussions regarding Tasmanian Aboriginal word usage. I am extremely grateful to Dr Garrick Hitchcock from the School ofCulture, History \& Language, Australian National University, for extensive discussions and his thoughtful editing of this manuscript.

\section{REFERENCES}

Allport, H. 1966: Gould, William Buelow (1801-1853). Australian Dictionary of Biography, National Centre of Biography, Australian National University, http://adb.anu.edu.au/ biography/gould-william-buelow-2114/text2669 (accessed 1 December 2017).

Anon. 2017: Tasmanian giant freshwater crayfish. Wikipedia, the free encyclopedia, https://en.wikipedia.org/wiki/ Tasmanian_giant_freshwater_crayfish (accessed 1 December 2017).

Avery, L. \& Austin, C.M. 1997: Biochemical Taxonomic Study of Spiny Crayfish of the Genera Astacopsis and Euastacus 

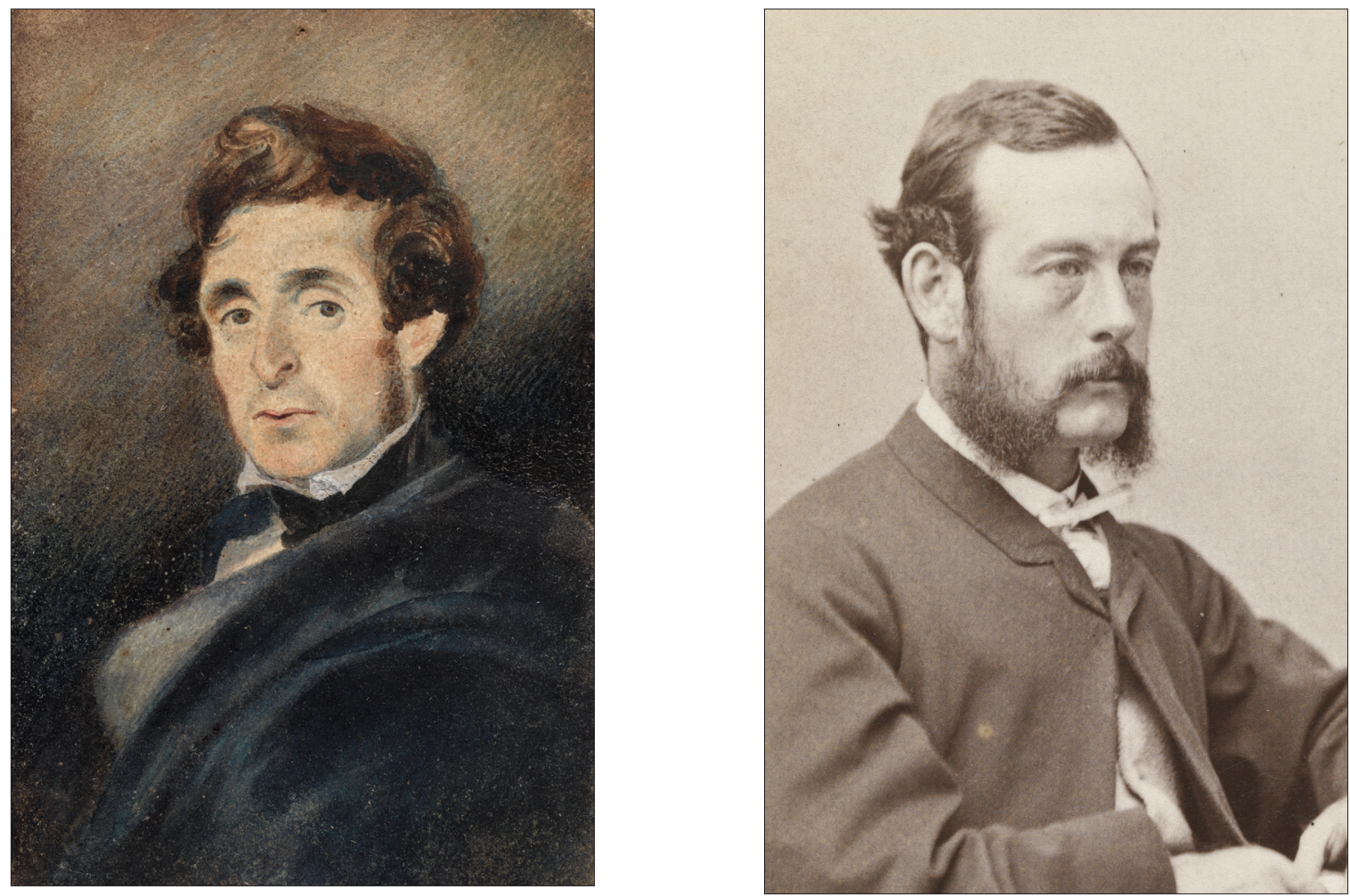

PLATE 3 -William Buelow Gould (1801-1853) and Charles Gould (1834-1893). Left: Portrait of William Buelow Gould c. 1840 by Thomas Bock [Reproduced with the permission of the Tasmanian Museum and Art Gallery]. Right: Photograph of Charles Gould by Charles Alfred Wooley, from the Allport Album XII. [Reproduced with the permission of the Allport Library and Museum of Fine Arts, Tasmanian Archive and Heritage Office.]

(Decapoda: Parastacidae) in South-Eastern Australia. Memoirs of the Museum of Victoria 56: 543-555.

Clark, E. 1936: The freshwater and land crayfishes of Australia. Memoirs of the National Museum of Victoria 10: 5-58.

Crawford, G.H., Ellis, W.F. \& Stancombe G.H. (eds) 1962: The Diaries of John Helder Wedge, 1824-1835. Royal Society of Tasmania, Hobart: 99 pp.

Erichson, W.F. 1846: Uebersicht der Arten der Gattung Astacus [Overview of the species of the genus Astacus]. Archiv für Naturgeschichte 12: 86-103.

Eyre, E.J. 1845: Journals of Expeditions of Discovery into Central Australia. T. \& W. Boone, London: 448 pp.

Flanagan, R. 2001: Gould's Book of Fish: A Novel in Twelve Fish. Pan Macmillan, Sydney: 404 pp.

Gan, H.M., Tan, M.H., Lee, Y.P., Schultz, M.B., Horwitz, P., Burnham, Q. \& Austin, C.M. 2017: More evolution underground: Accelerated mitochondrial substitution rate in Australian burrowing freshwater crayfishes (Decapoda: Parastacidae). Molecular Phylogenetics and Evolution 118: 88-98.

Gould, C. 1870: On the distribution and habits of the large fresh-water crayfish (Astacus sp.) of the northern rivers of Tasmania. Monthly Notices of Papers and Proceedings of the Royal Society of Tasmania: 42-44.

Gould, W.B. c. 1832: Sketchbook of Fishes in Macquarie Harbour. Bound volume of watercolours on paper, Allport Library and Museum of Fine Arts, State Library of Tasmania, Hobart.

Gray, J.E. 1845: Description of some New Australian Animals. In Eyre, E.J. Journals of Expeditions of Discovery into Central Australia, and Overland from Adelaide to King George's Sound, in the Years 1840-41. T. \& W. Boone, London: 405-411.

Hamr, P. 1992: A revision of the Tasmanian freshwater crayfish genus Astacopsis Huxley (Decapoda: Parastacidae). Papers and Proceedings of the Royal Society of Tasmania 126: 91-94.

Hiatt, B. 1967: The food quest and the economy of the Tasmanian Aborigines. Oceania 38(2): 99-133.

Hughes, R. 1987: The Fatal Shore. Collins Harvill, London: 688 pp.

Horwitz, P.H.J. 1990: A taxonomic revision of species in the freshwater crayfish genus Engaeus Erichson (Decapoda: Parastacidae). Invertebrate Taxonomy 4: 427-614.

Meade, I. 1959: William Buelow Gould-Convict Artist in Van Diemen's Land. Papers and Proceedings of the Royal Society of Tasmania 93: 81-88.

Milligan, J. 1859: On the dialects and language of the Aboriginal Tribes of Tasmania, and on their manners and customs. Papers and Proceedings of the Royal Society of Tasmania 3(2): 239-282.

National Library of Australia, 2007: W.B. Gould's Sketchbook of Fishes. National Treasures from Australia's Great Libraries exhibition, 2005-2007. http://nationaltreasures.nla.gov.au/ index/Treasures/item/nla.int-ex5-s2 (accessed 15 December 2017).

Noetling, F. 1910: The food of the Tasmanian Aborigines. Papers and Proceedings of the Royal Society of Tasmania: 279-305.

Plomley N.J.B. 1976: A Word-List of the Tasmanian Aboriginal Languages. Author in association with the Tasmanian Government, Hobart: 486 pp.

Plomley N.J.B. (ed.) 2008: Friendly Mission: The Tasmanian Journals and Papers of George Augustus Robinson 1829-1834. Queen Victoria Museum and Art Gallery and Quintus Press. University of Tasmania, Hobart, Australia: 1162 pp.

Riek, E.F. 1969: The Australian freshwater crayfish (Crustacea: Decapoda: Parastacidae), with descriptions of new species. Australian Journal of Zoology 17(5): 855-918. 
Reynolds, J., Souty-Grosset, C. \& Richardson, A. 2013: Ecological roles of crayfish in freshwater and terrestrial habitats. Freshwater Crayfish 19(2): 197-218.

Richardson, A. 2008: The Companion to Tasmanian History, Giant Freshwater Crayfish (Tayatea, Astacopsis Gouldi) http://www.utas.edu.au/library/companion_to_tasmanian_ history/G/Giant\%20freshwater\%20crayfish.htm. Accessed 14 December 2017.

Richardson, A. M. M. 2017: A range extension for the freshwater crayfish Geocharax tasmanicus (Erichson), with notes on its conservation status and specific name. The Tasmanian Naturalist 139: 63-67.

Richardson, A. Doran, N. \& Hansen, B. 2006: The geographic ranges of Tasmanian crayfish: extent and pattern. Freshwater Crayfish 15: 1-17.

Roth, H.L. 1899: The Aborigines of Tasmania. King \& Sons, Halifax: 228 pp

Shepherd, T. Gardner, C. Green, B.S. \& Richardson, A. 2011 Estimating survival of the Tayatea Astacopsis gouldi (Crustacea, Decapoda, Parastacidae), an iconic, threatened freshwater invertebrate. Journal of Shellfish Research 30(1): 139-145.

Sinclair, E.A., Madsen, A., Walsh, T., Nelson, J. \& Crandall, K.A. 2011: Cryptic genetic divergence in the giant Tasmanian freshwater crayfish Astacopsis gouldi (Decapoda: Parastacidae): implications for conservation. Animal Conservation 14(1): 87-97.
Smith G.W. 1908: The freshwater crustacea of Tasmania, with remarks on their geographical distribution. Transactions of the Linnean Society of London 11(4):61-92.

Smith, G. 1909: A Naturalist in Tasmania. Clarendon Press, Oxford: $151 \mathrm{pp}$.

Smith G. 1912: The Freshwater Crayfishes of Australia. Proceedings of the Zoological Society of London 82(1): 144-171.

Swain, R., Richardson, A.M.M. \& Hortle, M. 1982: Revision of the Tasmanian genus of freshwater crayfish Astacopsis Huxley (Decapoda: Parastacidae). Australian Journal of Marine and Freshwater Research 33(4): 699-709.

Tasmanian Aboriginal Centre, 2018 'palawa kani (Aborigines talking)' http://tacinc.com.au/programs/palawa-kani/ (accessed 30 April 2018)

Tasmanian Museum and Art Gallery, 2013: Shaping Tasmania: A Journey in 100 Objects, No. 48 Tasmania's Giant Freshwater Lobster - The World's Largest Freshwater Invertebrate, http://shapingtasmania.tmag.tas.gov.au/object.aspx?ID=48 (accessed 15 December 2017).

Threatened Species Section, 2006: Giant Freshwater Lobster Astacopsis gouldi Recovery Plan 2006-2010. Department of Primary Industries and Water, Hobart: 40 pp.

(accepted 7 August 2018) 